\title{
'Big science' spurs collaborative trend
}

\section{Complicated projects mean that science is becoming ever more globalized — and Europe is leading the way.}

It has never been a more fruitful time for collaborations with foreign scientists, and the European Union (EU) is leading the pack. Spurred by funding policies, half of EU research articles had international co-authors in 2007, more than twice the level of two decades ago, according to a major report released last week by the US National Science Foundation.

The EU level of international co-authorship is about twice that of the United States, Japan and India, but levels in these countries are rising - a sign of the continued allure of working across borders. "The phenomenon is across disciplines," says Loet Leydesdorff, a science-metrics expert at the University of Amsterdam. "You can find it everywhere."

András Schubert, editor of the journal Scientometrics and a researcher at the Institute for Science Policy Research in Budapest, Hungary, says that the rise in collaborations is partly out of necessity, corresponding with the rise of 'big science.' Many scientific endeavours - whether colliding particles or sequencing genomes have become more complicated, requiring the money and labour of many nations. But he says that collaborations have also emerged because of heightened possibilities: the Internet allows like-minded scientists to find each other, and dramatic drops in communications costs ease long-distance interactions. And there is a reward: studies of citation counts show that internationally co-authored papers have better visibility (O. Persson et al. Scientometrics 60, 421-432;

\section{The rise of Asia}

Global spending on research and development $(R \& D)$, totalling US\$1.1 trillion in 2007, has doubled in the past 11 years - growing faster than the global economy, according to a 15 January report by the US National Science Foundation. R\&D spending by Asian nations has surpassed that of the European Union (see chart), and is rising at a rate that could soon eclipse such spending in the United States.

Although this trend reflects the rise of China, it also results from better scientific infrastructure in nations such as India and South Korea. Science has become "democratized", says Rolf Lehming, programme director for the report, a biennial compendium of science data and metrics. "That opens up vast opportunities." E.H.
2004). "Scientists are motivated by vanity," says Schubert. "International collaboration is a way to propagate ideas in wider and wider circles."

Caroline Wagner, a research scientist at George Washington University in Washington DC and US chief executive of consulting company Science-Metrix in Alexandria, Virginia, notes that international collaborations offer additional flexibility. Whereas local collaborations sometimes persist past the point of usefulness because of social or academic obligations, international ones can be cultivated and dropped more freely.

The collaborative trend is true across scientific disciplines, although some fields have a greater eally have tendency for it. Particle physicists and astronomers collaborate often, for example, because they congregate at shared facilities such as particle colliders and observatories. Mathematicians, by contrast, tend historically towards solitude and lag behind other disciplines in the level of co-authorship - although, Wagner says, collaborations are rising there, too.

The level of collaboration also varies by country, as shown by the report's 'international collaboration index' (see table). Scandinavians are much more apt to collaborate with each other than, for example, the French are with the Germans, according to the index. "There are overlays of history, and political reasons, as to why collaborations emerge," says Wagner. Yet even below-average penchants for partnership (shown by values less than 1 ) have risen over the

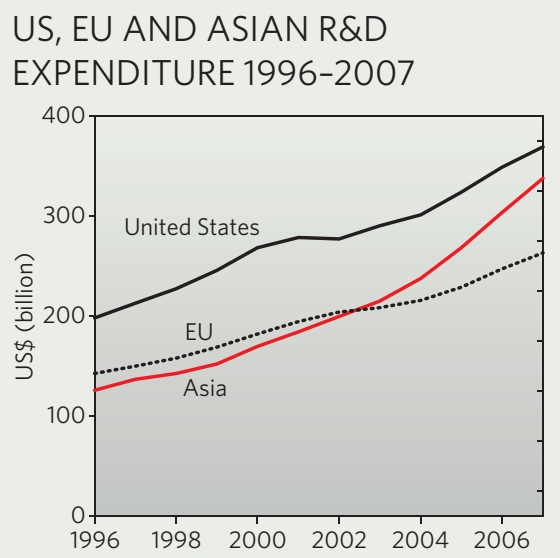

\begin{tabular}{|c|c|c|c|}
\hline Region & Country pair & $1998^{\star}$ & $2008^{\star}$ \\
\hline \multirow[t]{4}{*}{ North Atlantic } & US-UK & 0.67 & 0.74 \\
\hline & US-Germany & 0.68 & 0.68 \\
\hline & US-France & 0.56 & 0.60 \\
\hline & Canada-UK & 0.58 & 0.75 \\
\hline \multirow[t]{4}{*}{ Europe } & France-Germany & 0.74 & 0.91 \\
\hline & Germany-UK & 0.68 & 0.86 \\
\hline & Italy-Switzerland & 1.51 & 1.38 \\
\hline & Norway-Denmark & 4.35 & 4.13 \\
\hline \multirow[t]{3}{*}{ Americas } & Canada-US & 1.21 & 1.18 \\
\hline & US-Brazil & 0.87 & 0.89 \\
\hline & Argentina-Brazil & 4.33 & 5.32 \\
\hline \multirow[t]{4}{*}{ Pacific Rim } & Japan-US & 1.03 & 0.89 \\
\hline & China-US & 0.82 & 0.97 \\
\hline & Australia-China & 1.05 & 1.14 \\
\hline & $\begin{array}{l}\text { Australia-New } \\
\text { Zealand }\end{array}$ & 4.28 & 3.80 \\
\hline \multirow[t]{4}{*}{ Asia } & South Korea-Japan & 1.99 & 1.90 \\
\hline & India-Japan & 0.94 & 1.12 \\
\hline & India-China & 0.98 & 0.64 \\
\hline & China-Taiwan & 2.66 & 1.76 \\
\hline
\end{tabular}

*Values greater than 1 indicate more collaboration than expected; less than 1 , less collaboration than expected.

past decade - apparently boosted by policies embedded in European Framework funding schemes that require collaboration.

The United States tends to score below average because many researchers form within-country collaborations, says Rolf Lehming, director of the programme that produces the National Science Foundation report, Science and Engineering Indicators 2010. Relatively high index values for Asian country pairs suggest the birth of an intra-Asian zone of scientific collaboration (see 'The rise of Asia') - with the exception of collaborations between China and India, which dropped in the past decade, perhaps as they formed links with other countries.

But Wagner says that these national differences will become less meaningful as individual scientists enter a globalized science system that is open, undirected and ultimately more efficient: "What we really have is a breakdown of national concepts and national systems."

Eric Hand 